\title{
Przygotowanie pacjenta przewlekle chorego do samoopieki jako efekt skutecznej edukacji zdrowotnej prowadzonej przez pielęgniarkę
}

\author{
Preparing a chronically ill patient for self - care as a result \\ of effective health education conducted by a nurse
}

MAGDALENA ZAWIDZKA ${ }^{1}$, AGNIESZKA PIERNIKOWSKA²

${ }^{1}$ Studenckie Koło Naukowe Nauk o Zdrowiu, Instytut Nauk o Zdrowiu PWSZ
we Włocławku, opiekun Koła: dr Beata Haor
${ }^{2}$ Instytut Nauk o Zdrowiu Państwowej Wyższej Szkoły Zawodowej we Włocławku
3 III Oddział Chorób Wewnętrznych i Nefrologii, Wojewódzki Szpital Specjalistyczny
im. Bł. ks. J. Popiełuszki we Włocławku

DOI: http://dx.doi.org/10.21784//wP.2019.008

ISSN: 2451-1846

\section{Streszczenie:}

Wstęp. Edukacja zdrowotna to proces kształtowania u ludzi nawyku dbania o swoje zdrowie. Zadaniem pielęgniarki jest przygotowanie pacjenta przewlekle chorego i jego rodziny do samoopieki i samopielęgnacji na każdym etapie choroby, również w okresie terminalnym. Niezbędne jest kształtowanie umiejętności radzenia sobie z chorobą i niepełnosprawnością oraz udzielanie wsparcia psychicznego.

Cel. Celem badań była analiza opinii respondentów na temat wybranych aspektów edukacji zdrowotnej prowadzonej przez pielęgniarkę w odniesieniu do pacjenta przewlekle chorego.

Materiał i metody. Badania przeprowadzono wśród czynnych zawodowo pielęgniarek i pielęgniarzy. Wykorzystano metodę sondażu diagnostycznego, technikę ankietowania oraz autorski kwestionariusz ankiety. 
Wyniki. Większość respondentów podkreśla konieczność systematycznych działań pielęgniarek podejmowanych przez pielęgniarkę $\mathrm{w}$ ramach edukacji zdrowotnej pacjenta przewlekle

chorego.

Wnioski. Zdecydowana większość pielęgniarek potwierdza, że edukacja zdrowotna pacjenta przewlekle chorego jest konieczna. Niezbędne jest jednak zwiększenie nacisku na profesjonalne przygotowanie pielęgniarek do roli edukatora w ramach kształcenia przeddyplomowego i podyplomowego.

Słowa kluczowe. edukacja zdrowotna, choroba przewlekła, pacjent, pielęgniarka

\begin{abstract}
:
Introduction. Health education is the process of shaping the habit of caring for your health. The nurse's task is to prepare a chronically ill patient and his family to self-care at every stage of the disease, also during the terminal period. It is necessary to develop skills in coping with illness and disability and providing mental support.

Aim. The aim of the research was to analyze the respondents' opinions on selected aspects of health education conducted by a nurse in relation to a hronically ill patient.

Material and methods. The research was conducted among professionally active nurses. The method of diagnostic survey, questionnaire technique and author's questionnaire was used.

Results. Most respondents emphasize the necessity of systematic actions of nurses taken by a nurse in the framework of health education of a chronically ill patient.

Conclusion. The vast majority of nurses confirm that health education of a chronically ill patient is necessary. However, it is necessary to increase the emphasis on professional preparation of nurses for the role of an educator in undergraduate and postgraduate education.
\end{abstract}

Keywords: health education, chronic disease, patient, nurse 


\section{Wstęp}

Edukacja zdrowotna jest procesem, w którym człowiek winien jest wykorzystywać wiedzę w sposób jak najbardziej efektywny tzn. zastanawiając się, podejmując odpowiednie decyzje i działania, których następstwa będą miały znaczenie dla zarówno dla niego oraz dla społeczeństwa [1-3].

Edukacja zdrowotna ukierunkowana jest zatem do ludzi w różnym wieku oraz stanie zdrowia. Działania edukatora niezależnie od tego, czy osoba jest chora, zdrowa czy z niepełnosprawnościa, skierowane są zawsze na wzmacnianie i potęgowanie zdrowia. Edukacja obliguje do działań między sektorami życia społecznego, które mają charakter interdyscyplinarny $\mathrm{z}$ powodu złożoności problematyki, której dotyczą oraz umiejętności osób, odpowiedzialnych za ich prowadzenie $[2,4]$.

W ochronie zdrowia edukacja zdrowotna należy do działań obligatoryjnych, zarówno w odniesieniu do zadań zawodowych wykonywanych przez lekarza, pielęgniarkę, dietetyka, fizjoterapeutę oraz każdego innego członka wchodzącego w skład zespołu terapeutycznego, który zajmuje się pacjentem, a także jego rodziną. Edukacja zdrowotna pacjenta przewlekle chorego jest częścią składową postępowania terapeutycznego i powinna być obecna na każdym etapie leczenia. Umożliwia to pacjentowi podejmowanie świadomych decyzji dotyczących własnego zdrowia, zachęca do wykorzystywania posiadanej wiedzy oraz do dbania o własne zdrowie [2,4].

Edukacja zdrowotna jest nieodłącznym elementem opieki pielęgniarskiej realizowanej wobec pacjenta. To proces, którego ideą jest odpowiednie przygotowanie chorego do współdziałania w procesie pielęgnowania, leczenia, rehabilitacji, a także do świadczenia opieki nieprofesjonalnej. Stanowi zatem nieodłączny element przygotowania do samoopieki i samopielęgnacji. Pielęgniarki, które realizują edukację zdrowotną koncentrują swoje działania 
na kształtowaniu indywidualnych zachowań zdrowotnych człowieka zdrowego, zagrożonego chorobą czy wreszcie chorego [5,6].

Celem badań była analiza opinii respondentów na temat wybranych aspektów edukacji zdrowotnej, prowadzonej przez pielęgniarkę w odniesieniu do pacjenta przewlekle chorego.

\section{Materiał i metody}

Badania przeprowadzono wśród 184 pielęgniarek i pielęgniarzy $\mathrm{z}$ aktualnym prawem wykonywania zawodu. Wykorzystano metodę sondażu diagnostycznego, technikę ankietowania oraz autorski kwestionariusz ankiety.

\section{Wyniki}

Grupą badaną były pielęgniarki i pielęgniarze z aktualnym prawem wykonywania zawodu. Około $80 \%$ badanych stanowiły kobiety oraz mieszkańcy miasta (69\%). Średnia wieku respondentów wynosiła 38,85 natomiast średni staż pracy to około 15 lat. Zdecydowana większość badanych jest zatrudniona $\mathrm{w}$ szpitalach na oddziałach zabiegowych $(34,8 \%)$ i zachowawczych $(38 \%)$ oraz podstawowej opiece zdrowotnej (21,2\%); najmniej liczna zaś w: SOR i bloku operacyjnym (po 1,6\%), poradniach specjalistycznych, DPS-ach, w działach epidemiologii oraz diagnostyki obrazowej (po 0,5\%). Poniżej zaprezentowano wyniki badań własnych.

Tabela 1 przedstawia procentowy rozkład odpowiedzi na pytanie dotyczące konieczności prowadzenia edukacji zdrowotnej wobec pacjenta przewlekle chorego i jego rodziny. 
Tabela 1. Opinie badanych na temat konieczności prowadzenia edukacji zdrowotnej wobec pacjenta przewlekle chorego i jego rodziny.

\begin{tabular}{|l|l|l|}
\hline 1.Czy uważa Pan/ Pani, & Odpowiedzi \\
\cline { 2 - 3 } $\begin{array}{l}\text { że edukacja zdrowotna } \\
\text { pacjenta przewlekle } \\
\text { chorego i jego rodziny } \\
\text { jest konieczna? }\end{array}$ & $\%$ & N \\
\hline Tak & & \\
\hline Nie & $81 \%$ & 149 \\
\hline
\end{tabular}

Źródło: wynik badań własnych

Jak wynika z tabeli 1 większość respondentów (81\%) jest zdania, że edukacja pacjenta przewlekle chorego oraz jego najbliższych jest niezbędna. Natomiast 19\% badanych uważa, że takie działanie nie jest konieczne.

W tabeli 2 zaprezentowano opinie badanych dotyczące przekazywania materiałów edukacyjnych przez pielęgniarkę w czasie edukacji zdrowotnej, realizowanej wobec pacjenta przewlekle chorego i jego rodziny, w dążeniu do przygotowania do samoopieki w warunkach środowiska domowego. 
Tabela 2. Opinie badanych dotyczące przekazywania materiałów edukacyjnych przez pielęgniarkę w czasie edukacji zdrowotnej.

\begin{tabular}{|c|c|c|}
\hline \multirow{2}{*}{$\begin{array}{l}\text { 2.Czy w Pani/Pana ocenie, pielęgniarka w } \\
\text { ramach przygotowania pacjenta przewlekle } \\
\text { chorego i jego } \text { rodziny do } \\
\text { samoopieki/samopielęgnacji } w \text { warunkach } \\
\text { środowiska domowego powinna udostępniać } \\
\text { materiały edukacyjne } \text { np. broszury, } \\
\text { poradniki? }\end{array}$} & \multicolumn{2}{|c|}{ Odpowiedzi } \\
\hline & $\%$ & $\mathbf{N}$ \\
\hline Zawsze & $53 \%$ & 98 \\
\hline Często & $39 \%$ & 71 \\
\hline Sporadycznie & $8 \%$ & 15 \\
\hline
\end{tabular}

Źródło: wynik badań własnych

Jak wynika z tabeli 2 ponad połowa respondentów (53\%) odpowiedziała, że pielęgniarka powinna zawsze przekazywać pacjentowi niezbędne materiały edukacyjne. Zdaniem $39 \%$ badanych powinna robić to często a według 8\% ankietowanych - tylko sporadycznie.

W tabeli 3 przedstawiono opinie respondentów dotyczące nawiązania przez pielęgniarkę partnerskiego kontaktu $\mathrm{z}$ pacjentem $\mathrm{i}$ jego rodziną $\mathrm{w}$ ramach działań związanych $\mathrm{z}$ przygotowaniem do samoopieki/samopielęgnacji. 
Tabela 3. Opinie badanych dotyczące nawiązania przez pielęgniarkę partnerskiego kontaktu z pacjentem $\mathbf{i}$ jego rodziną w ramach prowadzonej edukacji zdrowotnej.

\begin{tabular}{|c|c|c|}
\hline \multirow[b]{2}{*}{$\begin{array}{lrr}\text { 3.Czy w } & \text { Pani/Pana } & \text { ocenie, } \\
\text { pielęgniarka w ramach przygotowania } \\
\text { pacjenta przewlekle chorego i jego } \\
\text { rodziny } & \text { do } \\
\text { samoopieki/samopielęgnacji } & \text { w } \\
\text { warunkach środowiska domowego } \\
\text { powinna nawiązać partnerski kontakt } \\
\text { z pacjentem i jego rodziną? }\end{array}$} & \multicolumn{2}{|c|}{ Odpowiedzi } \\
\hline & $\%$ & $\mathbf{N}$ \\
\hline Zawsze & $42 \%$ & 77 \\
\hline Często & $40 \%$ & 73 \\
\hline Sporadycznie & $18 \%$ & 34 \\
\hline
\end{tabular}

Źródło: wynik badań własnych

Zdaniem $42 \%$ ankietowanych należy zawsze nawiązać partnerski kontakt z pacjentem i jego rodziną w czasie przygotowania do samoopieki/samopielęgnacji. Natomiast $40 \%$ badanych twierdzi, iż należy często praktykować takie zachowanie. Zaledwie 18\% respondentów uważa, że należy robić do sporadycznie.

W tabeli 4 zaprezentowano opinie respondentów dotyczące zachęcania przez pielęgniarki pacjentów do rezygnacji ze stosowania używek, środków psychoaktywnych oraz wspierania ich w podjęciu decyzji o leczeniu uzależnień. 
Tabela 4. Opinie badanych dotyczące zachęcania pacjentów w ramach edukacji zdrowotnej do rezygnacji ze stosowania używek, środków psychoaktywnych oraz wspierania ich w podjęciu decyzji o terapii uzależnień.

\begin{tabular}{|c|c|c|}
\hline \multirow[b]{2}{*}{$\begin{array}{l}\text { 4. Czy w Pani/Pana ocenie, pielęgniarka } \\
\text { w ramach przygotowania pacjenta } \\
\text { przewlekle chorego i jego rodziny do } \\
\text { samoopieki/samopielęgnacji } \\
\text { w warunkach środowiska domowego } \\
\text { powinna zachęcać pracjenta } \\
\text { do rezygnacji ze stosowania używek } \\
\text { i stosowania środków psychoaktywnych } \\
\text { oraz wspierać w podjęciu leczenia } \\
\text { uzależnień? }\end{array}$} & \multicolumn{2}{|c|}{ Odpowiedzi } \\
\hline & $\%$ & $\mathbf{N}$ \\
\hline Zawsze & $57 \%$ & 105 \\
\hline Często & $29 \%$ & 53 \\
\hline Sporadycznie & $14 \%$ & 26 \\
\hline
\end{tabular}

Źródło: wynik badań własnych

Jak wynika z tabeli 4 ponad połowa badanych (57\%) uważa, że pielęgniarka powinna zawsze zachęcać do podjęcia decyzji o zaprzestaniu przyjmowania środków psychoaktywnych oraz wspierać $\mathrm{w}$ podejmowaniu decyzji o podjęciu terapii uzależnień. Zdaniem 29\% ankietowanych należy robić to często, natomiast $14 \%$ respondentów uważa, że tylko sporadycznie.

W tabeli 5 przedstawiono opinie respondentów dotyczące angażowania pacjentów do działań w ramach samokontroli przebiegu choroby przewlekłej. 
Tabela 5. Opinie badanych dotyczące przygotowania pacjentów do samokontroli przebiegu choroby przewlekłej.

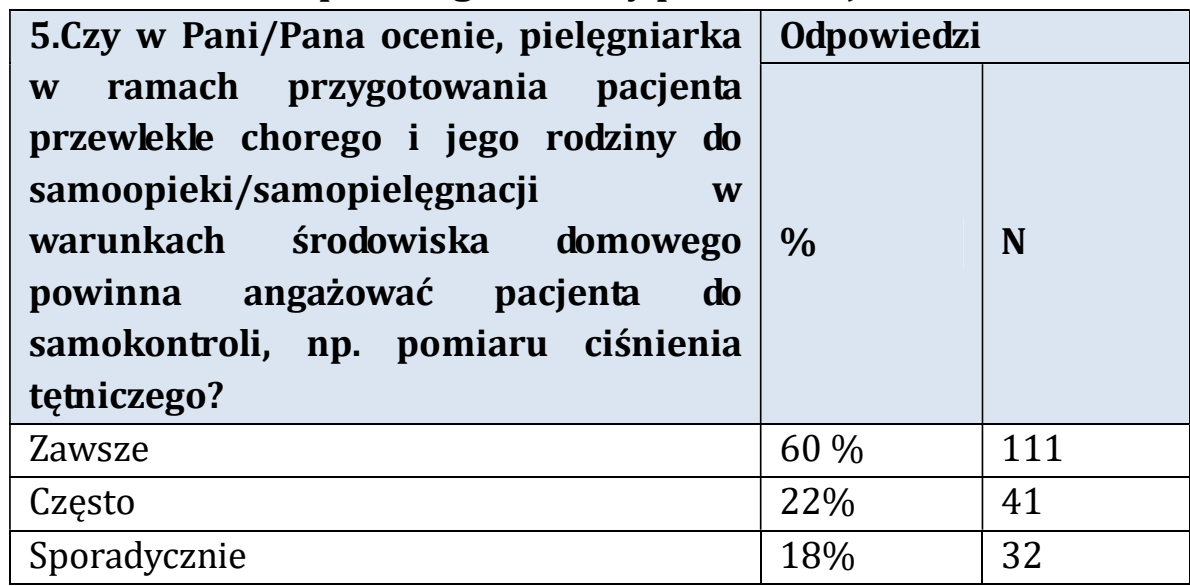

Źródło: wynik badań własnych

Jak wynika z tabeli 5większość ankietowanych (60\%) twierdzi, iż zawsze należy angażować pacjenta do działań w ramach samokontroli przebiegu choroby przewlekłej np. samodzielnego pomiaru ciśnienia tętniczego krwi. Z kolei 22\% respondentów jest zdania, że takie działania należy przeprowadzać często. Natomiast 18\% badanych uważa, że można to ograniczyć do sporadycznego angażowania do samokontroli.

W tabeli 6 zaprezentowano opinie respondentów dotyczące mobilizowania przez pielęgniarkę pacjenta do zmiany trybu życia i podjęcia aktywności fizycznej $\mathrm{w}$ ramach prowadzonej edukacji zdrowotnej. 
Tabela 6. Opinie badanych dotyczące mobilizowania pacjenta do zwiększenia aktywności fizycznej w ramach prowadzonej edukacji zdrowotnej.

\begin{tabular}{|c|c|c|}
\hline \multirow{2}{*}{$\begin{array}{l}\text { 6.Czy w Pani/Pana ocenie, pielęgniarka } \\
\text { w ramach przygotowania pacjenta } \\
\text { przewlekle chorego i jego rodziny do } \\
\text { samoopieki/samopielęgnacji } \\
\text { warunkach środowiska domowego } \\
\text { powinna mobilizować pacjenta do } \\
\text { zmiany trybu życia i podjęcia aktywności } \\
\text { fizycznej? }\end{array}$} & \multicolumn{2}{|c|}{ Odpowiedzi } \\
\hline & $\%$ & $\mathbf{N}$ \\
\hline Zawsze & $56 \%$ & 103 \\
\hline Często & $34 \%$ & 63 \\
\hline Sporadycznie & $10 \%$ & 18 \\
\hline
\end{tabular}

Źródło: wynik badań własnych

Jak wynika z tabeli 6 ponad połowa badanych (56\%) jest zdania, że zawsze należy zachęcać pacjenta do zmiany trybu życia oraz podjęcia aktywności fizycznej. Zdaniem 34\% ankietowanych należy robić to często a w opinii $10 \%$ respondentów sporadyczna zachęta w tym zakresie jest wystarczająca.

W tabeli 7 przedstawiono opinie respondentów dotyczące informowania przez pielęgniarkę o czynnikach ryzyka powikłań choroby w ramach prowadzonej edukacji zdrowotnej. 
Tabela 7. Opinie badanych dotyczące informowania przez pielęgniarkę o czynnikach ryzyka powikłań choroby przewlekłej w ramach prowadzonej edukacji zdrowotnej.

\begin{tabular}{|c|c|c|}
\hline \multirow{2}{*}{$\begin{array}{l}\text { 7.Czy w Pani/Pana ocenie, pielęgniarka } \\
\text { w ramach przygotowania pacjenta } \\
\text { przewlekle chorego i jego rodziny do } \\
\text { samoopieki/samopielęgnacji } \\
\text { warunkach środowiska domowego } \\
\text { powinna informować o czynnikach } \\
\text { ryzyka powikłań w przebiegu choroby? }\end{array}$} & \multicolumn{2}{|c|}{ Odpowiedzi } \\
\hline & $\%$ & $\mathbf{N}$ \\
\hline Zawsze & $59 \%$ & 109 \\
\hline Często & $25 \%$ & 45 \\
\hline Sporadycznie & $16 \%$ & 30 \\
\hline
\end{tabular}

Źródło: wynik badań własnych

Jak wynika z tabeli 7 większość badanych (60\%) uważa, iż należy zawsze informować pacjenta i jego rodzinę o czynników ryzyka dotyczących możliwych powikłań w przebiegu choroby przewlekłej. Natomiast 25\% ankietowanych jest zdania, że należy robić to często. Zadaniem $16 \%$ badanych wystarczy robić to tylko sporadycznie.

W tabeli 8 zaprezentowano opinie ankietowanych dotyczące przekazywania przez pielęgniarkę informacji nt. zasad przyjmowania leków i ich interakcji z innymi lekami, ziołami oraz suplementami, z których pacjent korzysta bez zlecenia lekarskiego. 
Tabela 8. Opinie badanych dotyczące przekazywania w czasie edukacji zdrowotnej informacji nt. zasad przyjmowania leków i ich interakcji $z$ innymi lekami, ziołami oraz suplementami, z których pacjent korzysta bez zlecenia lekarskiego.

\begin{tabular}{|c|c|c|}
\hline \multirow[b]{2}{*}{$\begin{array}{l}\text { 8.Czy w Pani/Pana ocenie w ramach } \\
\text { przygotowania pacjenta przewlekle } \\
\text { chorego i jego rodziny do } \\
\text { samoopieki/samopielęgnacji } \\
\text { warunkach środowiska domowego, } \\
\text { pielęgniarka powinna przekazać zasady } \\
\text { przyjmowania leków oraz ich interakcji } \\
\text { z innymi lekami, ziołami, suplementami } \\
\text { diety, które pacjent przyjmuje bez } \\
\text { zlecenia lekarskiego? }\end{array}$} & \multicolumn{2}{|c|}{ Odpowiedzi } \\
\hline & $\%$ & $\mathbf{N}$ \\
\hline Zawsze & $53 \%$ & 98 \\
\hline Często & $29 \%$ & 53 \\
\hline Sporadycznie & $18 \%$ & 33 \\
\hline
\end{tabular}

Źródło: wynik badań własnych

Jak wynika $\mathrm{z}$ tabeli 8 ponad połowa ankietowanych (53\%)uważa, że zawsze należy informować pacjenta o zasadach przyjmowania leków oraz ich możliwych działaniach niepożądanych. Natomiast $29 \%$ badanych twierdzi, że należy robić to często a $18 \%$ respondentów jest zdania, iż uświadamianie pacjenta w tym zakresie można ograniczyć do sporadycznego działania.

W tabeli 9 przedstawiono opinie ankietowanych dotyczące przedstawiania przez pielęgniarkę informacji nt. zasad pielęgnacji rany przewlekłej. 
Tabela 9. Opinie badanych dotyczące przedstawiania informacji nt. zasad pielęgnacji rany przewlekłej $w$ ramach edukacji zdrowotnej.

\begin{tabular}{|c|c|c|}
\hline \multirow{2}{*}{$\begin{array}{l}\text { 9.Czy w Pani/Pana ocenie } w \text { ramach } \\
\text { przygotowania pacjenta przewlekle } \\
\text { chorego i jego rodziny do } \\
\text { samoopieki/samopielęgnacji } \\
\text { warunkach środowiska domowego } \\
\text { pielęgniarka powinna przedstawiać } \\
\text { zasady pielęgnacji rany przewlekłej? }\end{array}$} & \multicolumn{2}{|c|}{ Odpowiedzi } \\
\hline & $\%$ & $\mathbf{N}$ \\
\hline Zawsze & $61 \%$ & 113 \\
\hline Często & $28 \%$ & 51 \\
\hline Sporadycznie & $11 \%$ & 20 \\
\hline
\end{tabular}

Źródło: wynik badań własnych

Jak wynika z tabeli 9 większość badanych (61\%) potwierdziło, że pielęgniarka powinna zawsze przedstawiać zasady pielęgnacji rany przewlekłej. Natomiast28\%respondentów uważa, że należy robić to często. Zdaniem 11\% ankietowanych takie informacje należy przekazywać sporadycznie.

W tabeli 10 zaprezentowano opinie ankietowanych dotyczące zachęcania pacjenta przez pielęgniarkę do skorzystania $\mathrm{z}$ porad i wsparcia, które jest udzielane w specjalistycznych poradniach, m.in. zdrowia psychicznego. 
Tabela 10. Opinie badanych dotyczące zachęcania pacjenta do korzystania $z$ porad $i$ wsparcia oferowanych w specjalistycznych poradniach.

\begin{tabular}{|c|c|c|}
\hline \multirow{2}{*}{$\begin{array}{l}\text { 10.Czy w Pani/Pana ocenie w ramach } \\
\text { przygotowania pacjenta przewlekle } \\
\text { chorego i jego rodziny do } \\
\text { samoopieki/samopielęgnacji } \\
\text { warunkach środowiska domowego } \\
\text { pielęgniarka powinna zachęcać do } \\
\text { skorzystania z porad i wsparcia } \\
\text { udzielanego } \quad \text { w } \text { specjalistycznych } \\
\text { poradniach np. zdrowia psychicznego? }\end{array}$} & \multicolumn{2}{|c|}{ Odpowiedzi } \\
\hline & $\%$ & $\mathbf{N}$ \\
\hline Zawsze & $46 \%$ & 84 \\
\hline Często & $34 \%$ & 63 \\
\hline Sporadycznie & $20 \%$ & 37 \\
\hline
\end{tabular}

Źródło: wynik badań własnych

Jak wynika z tabeli 10 zdaniem blisko połowy ankietowanych (46\%)pielęgniarka zawsze powinna zachęcać pacjenta do korzystania zoferty wsparcia informacyjnego oferowanego $\mathrm{w}$ poradniach specjalistycznych. Około $34 \%$ badanych twierdzi, że należy robić to często, zaś 20\%ankietowanych jest zadania, że takie działania można wykonywać sporadycznie.

W tabeli 11 zaprezentowano opinie respondentów dotyczące uwzględniania $w$ ramach edukacji zdrowotnej prowadzonej wobec pacjenta chorego przewlekle i jego rodziny informacji nt. przestrzegania zasad higieny. 
Tabela 11. Opinie badanych dotyczące uwzględniania $w$ ramach edukacji zdrowotnej informacji nt. przestrzegania zasad higieny.

\begin{tabular}{|c|c|c|}
\hline \multirow{2}{*}{$\begin{array}{l}\text { 11.Czy w Pani/Pana ocenie } \text { wramach } \\
\text { przygotowania pacjenta przewlekle } \\
\text { chorego i jego rodziny do } \\
\text { samoopieki/samopielęgnacji } r \\
\text { warunkach środowiska domowego } \\
\text { pielęgniarka powinna uwzględniać } \\
\text { edukację nt. przestrzegania zasad } \\
\text { higieny przez pacjenta? }\end{array}$} & \multicolumn{2}{|c|}{ Odpowiedzi } \\
\hline & $\%$ & $\mathbf{N}$ \\
\hline Zawsze & $61 \%$ & 113 \\
\hline Często & $25 \%$ & 45 \\
\hline Sporadycznie & $14 \%$ & 26 \\
\hline
\end{tabular}

Źródło: wynik badań własnych

Jak wynika z tabeli 11 większość badanych (61\%) wskazuje, iż zawsze należy uwzględniać w ramach edukacji zdrowotnej tematykę dotyczącą higieny osobistej. Natomiast $25 \%$ respondentów twierdzi, że omawianie zasad przestrzegania higieny trzeba przeprowadzać często. Z kolei $14 \%$ ankietowanych uważa, że takie działania można wykonywać sporadycznie.

W tabeli 12 przedstawiono opinie respondentów dotyczące zachęcania pacjenta przez pielęgniarkę do udziału w badaniach realizowanych w ramach programów profilaktycznych. 
Tabela 12. Opinie badanych nt. zachęcania pacjenta $w$ ramach edukacji zdrowotnej do udziału $w$ badaniach realizowanych w ramach programów profilaktycznych.

\begin{tabular}{|c|c|c|}
\hline \multirow{2}{*}{$\begin{array}{l}\text { 12. Czy w Pani/Pana ocenie w ramach } \\
\text { przygotowania pacjenta przewlekle } \\
\text { chorego i jego rodziny do } \\
\text { samoopieki/samopielęgnacji } \\
\text { warunkach środowiska domowego } \\
\text { pielęgniarka powinna zachęcać pacjenta } \\
\text { do udziału w badaniach realizowanych w } \\
\text { ramach programów profilaktycznych? }\end{array}$} & \multicolumn{2}{|c|}{ Odpowiedzi } \\
\hline & $\%$ & $\mathbf{N}$ \\
\hline Zawsze & $46 \%$ & 85 \\
\hline Często & $41 \%$ & 75 \\
\hline Sporadycznie & $13 \%$ & 24 \\
\hline
\end{tabular}

Źródło: wynik badań własnych

Jak wynika z tabeli 12 blisko połowa badanych (46\%) jest zdania, że pielęgniarka zawsze powinna zachęcać pacjenta do udziału w programach profilaktycznych. Zdaniem $41 \%$ ankietowanych takie działanie powinno być częste a $13 \%$ badanych twierdzi, że tylko sporadyczne.

W tabeli 13 zaprezentowano opinie respondentów dotyczące posługiwania się przez pielęgniarkę prostym i zrozumiałym językiem dla pacjenta i jego rodziny w czasie prowadzonej edukacji zdrowotnej. 
Tabela 13. Opinie badanych nt. posługiwania się prostym i zrozumiałym językiem dla pacjenta $i$ jego rodziny $w$ czasie prowadzonej edukacji zdrowotnej.

\begin{tabular}{|l|l|l|}
\hline 13.Czy w Pani/Pana ocenie w ramach & Odpowiedzi \\
przygotowania pacjenta przewlekle & & \\
chorego i jego rodziny do & & \\
samoopieki/samopielęgnacji domowego & $\%$ & N \\
warunkach środowiska doma & & \\
pielęgniarka powinna posługiwać się & & \\
prostym i zrozumiałym językiem dla & & \\
pacjenta? & & \\
\hline Zawsze & $67 \%$ & 124 \\
\hline Często & $20 \%$ & 36 \\
\hline Sporadycznie & $13 \%$ & 24 \\
\hline
\end{tabular}

Źródło: wynik badań własnych

Jak wynika z tabeli 13 większość ankietowanych (67\%) jest zdania, że pielęgniarka zawsze $\mathrm{w}$ czasie prowadzonej edukacji zdrowotnej powinna się posługiwać się jeżykiem zrozumiałym dla pacjenta i jego rodziny. Zdaniem $20 \%$ badanych wystarczy, że robi to często. Natomiast $13 \%$ ankietowanych twierdzi, że sporadycznie należy używać zrozumiałej terminologii wobec pacjenta i jego rodziny.

W tabeli 14 przedstawiono opinie ankietowanych dotyczące przeprowadzania przez pielęgniarkę instruktażu w zakresie zasad zabezpieczenia i przystosowania środowiska zamieszkania do sytuacji zdrowotnej pacjenta chorego przewlekle. 
Tabela 14. Opinie badanych nt. przeprowadzania $w$ ramach edukacji zdrowotnej instruktażu w zakresie zasad zabezpieczenia i przystosowania środowiska zamieszkania do sytuacji zdrowotnej pacjenta chorego przewlekle.

\begin{tabular}{|c|c|c|}
\hline \multirow[b]{2}{*}{$\begin{array}{l}\text { 14. Czy w Pani/Pana ocenie w ramach } \\
\text { przygotowania pacjenta przewlekle } \\
\text { chorego i jego rodziny do } \\
\text { samoopieki/samopielęgnacji r } \\
\text { warunkach środowiska domowego } \\
\text { pielęgniarka powinna przeprowadzać } \\
\text { instruktaż w zakresie zasad } \\
\text { zabezpieczenia i przystosowania } \\
\text { środowiska zamieszkania do sytuacji } \\
\text { zdrowotnej pacjenta? }\end{array}$} & \multicolumn{2}{|c|}{ Odpowiedzi } \\
\hline & $\%$ & $\mathbf{N}$ \\
\hline Zawsze & $52 \%$ & 95 \\
\hline Często & $32 \%$ & 59 \\
\hline Sporadycznie & $16 \%$ & 30 \\
\hline
\end{tabular}

Źródło: wynik badań własnych

Jak wynika $\mathrm{z}$ tabeli 14 ponad połowa ankietowanych (52\%) jest zdania, że zawsze należy przeprowadzać stosowny instruktaż pacjenta i jego rodziny nt. optymalnego przygotowania bezpiecznego środowiska domowego dla potrzeb osoby chorej przewlekle. Natomiast $32 \%$ badanych uważa, że należy robić to często. Zdaniem $16 \%$ badanych takie działanie można wykonać sporadycznie.

Tabela 15 przedstawia procentowy rozkład odpowiedzi na pytanie dotyczące konieczności położenia szczególnego nacisku na przygotowanie pielęgniarek do roli edukatora zdrowia w ramach kształcenia przed- i podyplomowego. 
Tabela 15. Opinie badanych nt. przygotowania pielęgniarek do roli edukatora zdrowia $w$ ramach kształcenia przedi podyplomowego.

\begin{tabular}{|l|l|l|}
\hline 15.Czy w Pani/Pana ocenie w & Odpowiedzi \\
\cline { 2 - 3 } $\begin{array}{l}\text { kształceniu przed-oraz } \\
\text { podyplomowym pielęgniarek } \\
\text { należy położyć szczególny } \\
\text { nacisk na ich przygotowanie } \\
\text { do roli edukatora zdrowia? }\end{array}$ & \% & $\mathbf{N}$ \\
\hline Tak & $69 \%$ & \\
\hline Nie & $32 \%$ & 126 \\
\hline
\end{tabular}

Źródło: wynik badań własnych

Zdecydowana większość badanych $(68,5 \%)$ uważa, iż należy położyć szczególny nacisk na przygotowanie pielęgniarek do roli edukatora zdrowia, zarówno $\mathrm{w}$ ramach kształcenia przedi podyplomowego. Natomiast $31,5 \%$ ankietowanych twierdzi, że nie należy przykładać wagi do przygotowania personelu pielęgniarskiego do takiego zadania.

\section{Dyskusja}

Czynności realizowane przez pielęgniarkę w ramach edukacji zdrowotnej powinny być spójnie i logicznie powiązane w odpowiednie struktury. Niezbędnej jest zatem, aby były rozumiane i podejmowane jako proces działania zorganizowanego, który posiada odpowiednią strukturę czyli takie elementy jak: rozpoznanie, planowanie, realizacja oraz ocena [5].

Pielęgniarka jako aktywny edukator zdrowia powinna wykorzystać każdą sytuację do przekazania wiedzy pacjentowi oraz wdrożenia do prezentowania pozytywnych zachowań zdrowotnych. Niezbędna jest oczywiście $w$ tym zakresie interdyscyplinarna 
współpraca $\quad \mathrm{z} \quad$ członkami zespołu terapeutycznego. Dzięki systematycznej pracy z pacjentem i jego rodziną pielęgniarka może osiągnąć zadowalające wyniki edukacji zdrowotnej w krótkim czasie. Istotnym etapem tych działań jest ewaluacja procesu i wyniku. Aktualne podejście do edukacji zdrowotnej wskazuje, iż ważniejsze jest to, ile uzyskano w jej efekcie, a nie to, ile zostało zrobione [2].

Analiza badań własnych wykazuje, że w opinii zdecydowanej większości pielęgniarek i pielęgniarzy edukacja zdrowotna pacjenta przewlekle chorego i jego rodziny jest niezbędna do optymalnego przygotowania odbiorców świadczeń do opieki nieprofesjonalnej. Jednakże jest to nadal zaniedbywany obszar opieki pielęgniarskiej realizowanej wobec pacjenta, pomimo tego, że jest istotnym ogniwem poprawy jakości świadczeń medycznych [7].

Pielęgniarka realizująca funkcję wychowawczą wobec pacjenta i jego rodziny, odpowiedzialna jest za m.in. motywowanie chorego do zmian na rzecz własnego zdrowia oraz angażowania do samokontroli tak, aby umożliwić osiągnięcie zdolności do samoopieki. Wyniki badań prowadzone przez innych badaczy[8] wskazują, że połowa ankietowanych pacjentów twierdzi, że pielęgniarki prowadzą edukację zdrowotną dotyczącą zmiany nawyków żywieniowych oraz zachęcają do podjęcia aktywności fizycznej. Niestety wspomniani respondenci mają zastrzeżenia co do jakości przekazywanych informacji. Powyższe spostrzeżenie znajduje swoiste potwierdzenie w wynikach badań własnych. Około $13 \%$ badanych pielęgniarek było bowiem zdania, że używanie prostego i zrozumiałego języka dla pacjenta powinno być czynnością sporadyczną. Wg badań A. Jurkiewicz zaledwie 35\% ankietowanych pacjentów wyraziło pozytywną opinię nt. jasności przekazywanych informacji przez pielęgniarkę [9]. Podstawą edukacji zdrowotnej jest zatem odpowiednia komunikacja między pacjentem a pielęgniarką [10].

W ocenie większości pielęgniarek/ pielęgniarzy w badaniach własnych przekazanie materiałów edukacyjnych jest koniecznym 
elementem edukacji zdrowotnej, tak samo jak nawiązanie partnerskiego kontaktu z pacjentem i jego rodziną. Większość respondentów jest zdania, iż zawsze należy przekazywać pacjentom przewlekle chorym wiedzę nt. pielęgnacji ran przewlekłych oraz zasad przyjmowania leków. Niepokojącym zjawiskiem jest to, że kilkanaście procent pielęgniarek i pielęgniarzy uważa, że sporadyczne przekazywanie informacji o czynnikach ryzyka powikłań chorób przewlekłych czy okazjonalne zachęcanie do korzystania z programów profilaktycznych i poradni specjalistycznych jest wystarczające.

\section{Wnioski}

Zdecydowana większość pielęgniarek/pielęgniarzy potwierdza, że edukacja zdrowotna pacjenta przewlekle chorego jest konieczna w kontekście przygotowania do świadomej samoopieki i samopielęgnacji. Niezbędne jest jednak zwiększenie nacisku na profesjonalne przygotowanie pielęgniarek do roli edukatora w ramach kształcenia przeddyplomowego i podyplomowego.

\section{Zalecenia dla praktyki pielęgniarskiej}

Edukacja zdrowotna powinna być nieodłącznym elementem świadczeń zdrowotnych udzielanych przez pielęgniarkę pacjentowi choremu przewlekle i jego rodzinie. Skuteczność takich działań jest uwarunkowana ich systematycznością, planowaniem i ewaluacją w wymiarze długoterminowym, przestrzeganiem zasad komunikacji interpersonalnej i terapeutycznej, doborem metod i środków edukacji zdrowotnej, adekwatnych do potrzeb odbiorców świadczeń. 


\section{Bibliografia / Bibliography:}

1.Gregorowicz- Warpas D. Metody edukacji pacjentów i ich rodzin w zakresie profilaktyki oraz zwalczania zakażeń. Forum Zakażeń. 2018;9 (1):33 - 37.

2. Woynarowska B. Edukacja zdrowotna. Wyd. Naukowe PWN, Warszawa 2017.

3. Andruszkiewicz A., Banaszkiewicz M. Promocja zdrowia. Teoretyczne podstawy promocji zdrowia. Tom 1. Czelej, Lublin 2008.

4. Pabiś M., Ślusarska B., Jarosz M.J., Zarzycka D., Dobrowolska B., Brzozowska A. Kompetencje pielęgniarek w zakresie edukacji zdrowotnej w polskim systemie opieki medycznej. Pielęgniarstwo XXI wieku. 2010;3-4 $(32-33): 75-85$.

5. Ciechaniewicz W. Pedagogika. PZWL. Warszawa 2008.

6. Rush K., Kee C., Rice M. Nurses as imperfect role models for health promotion. Western Journal of Noursing Research. 2005; 27 (2):166 - 183.

7. Ślusarz R. i wsp. Samoocena pielęgniarek neurochirurgicznych w zakresie wybranych aspektów opieki. W: Krajewska K.i wsp. (red.), Problemy terapeutyczno - pielęgnacyjne: od poczęcia do starości. AM w Białymstoku, Białystok 2007;123 - 128.

8. Glińska J. i wsp. Analiza poziomu jakości opieki w opinii pielęgniarek i pacjentów. Piel. Chir. Angiol. 2012;4:151 - 160.

9. Jurkiewicz A., Kobos E.Opinia pacjentów na temat pracy pielęgniarek. Pielęgniarstwo Polskie.2017, 3 (65):473 - 480.

10. Kler M. Komunikacja interpersonalna. Mag. Piel. Położ. 2015;11:40 - 41. 
Otrzymano: 05.03.2019r.

Zaakceptowano: 11.04.2019r. 